\title{
Nature of brood signal activating the protein synthesis of hypopharyngeal gland in honey bees, Apis mellifera (Api- dae : Hymenoptera)
}

\author{
Z.-Y. Huang ${ }^{1 *}$, G.W. Otis ${ }^{1}$, and P.E.A. Teal 2 \\ 1 University of Guelph, Department of Environmental Biology, Guelph, Ontario, N1G 2W1 Canada \\ 2 USDA, Insect Attractants Laboratory, PO Box 14565, Gainesville, FL 32604, USA
}

(received 4 December 1988, accepted 26 June 1989)

\begin{abstract}
Summary - Evidence suggests the existence of a signal from honey bee brood which activates the protein synthesis of hypopharyngeal glands of nurse honey bees. An in vitro bioassay, modified from Brouwers (1982), was used to measure protein synthesis in glands from bees reared under different treatments. By using colonies divided into brood-right and broodless portions with single or double screens, it was found that the signal can only be obtained by worker bees if they have direct access to the brood. Alternative hypotheses, such as the signal being a highly volatile chemical, or a stimulus transferable through antennal signaling or through trophallaxis, were ruled out by the experimental design. Regression analysis showed that there was a quadratic relationship between total protein content and synthetic activity of hypopharyngeal glands, which indicated that both undeveloped and hypertrophied glands were less actively synthesizing protein than those glands of intermediate sizes.
\end{abstract}

Apis mellifera - hypopharyngeal gland — proteln synthesis - brood

\section{INTRODUCTION}

Larvae of the honey bee (Apis mellifera L.) depend completely on adult worker bees for their food. An important component of the larval food is a proteinaceous secretion of the hypopharyngeal (HP) glands (JungHoffmann, 1966). During summer, the lar- vae are fed by nurse bees 5 to 20 daysold with fully developed HP glands which show high rates of protein synthesis (Brouwers, 1982). In winter, when there is no brood in the colony, the glands are fully developed (hypertrophied), yet demonstrate low rates of protein synthesis. However, when the queen starts laying in the spring, or when brood is introduced artifi-

\footnotetext{
* Present address : University of Missouri-Columbia; Department of Entomology; 1-87 Agriculture Building; Columbia, MO 65211, USA
} 
cially, protein synthesis of HP glands is activated and increases to a maximum within 3 days (Brouwers, 1982, 1983).

The activation of HP glands appears to be a complicated process. Juvenile hormone $(\mathrm{JH})$ has been shown to control the development of this gland (Rutz et al., 1976; Fluri et al., 1982). Buhler et al. (1983) indicated that the higher temperature and carbon dioxide concentration associated with brood rearing could induce a pronounced increase in $\mathrm{JH}$ titre. It was possible that the increased $\mathrm{JH}$ titre could in turn activate protein synthesis in the HP glands. However, JH alone does not stimulate protein synthesis in winter bees (with well-developed HP glands) in absence of the brood (Brouwers, 1983). Accordingly, even though $\mathrm{JH}$ may be controlling the development of the HP glands, the developed glands are not necessarily actively synthesizing protein. It was shown that winter bees, although with hypertrophied HP glands, show a low rate of protein synthesis (Brouwers, 1982); as do broodless bees in summer (Brouwers, 1982; Huang \& Otis, 1989). Huang (1988) hypothesized that once the HP glands are well developed, possibly under the control of a rising titre of $\mathrm{JH}$, further production (or injection) of $\mathrm{JH}$ would actually inhibit its development. Furthermore, a signal(s) from the brood appears to exist which initiates and maintains the protein synthesizing process in those already developed HP glands. The study reported here is part of a series of experiments carried out to investigate the properties and mode of action of the signal (Huang, 1988; Huang \& Otis, 1989). For simplification, "signal" will be used throughout this paper, but it does not exclude the possibility that there may in fact be several signals acting in concert.

By using colonies divided into broodright and broodless portions with either single or double-screens (Fig. 1A), and comparing the in vitro activity of the HP glands of bees from the different colony treatments, this study was conducted to test if the signal from the brood fits one of three alternative hypotheses concerning its nature (Fig. 1B).

Determination of the total protein content for each pair of glands was used as estimates of their sizes. Although the protein content of glands does not strictly measure gland size, there is apparently a positive relationship between the two (see Fig. 2 of Brouwers, 1982). If there was a correlation between gland size and rates of protein synthesis, treatment effects could be adjusted accordingly.

\section{MATERIALS AND METHODS}

Experiments were carried out between May and August, 1984. Honey bees used throughout the

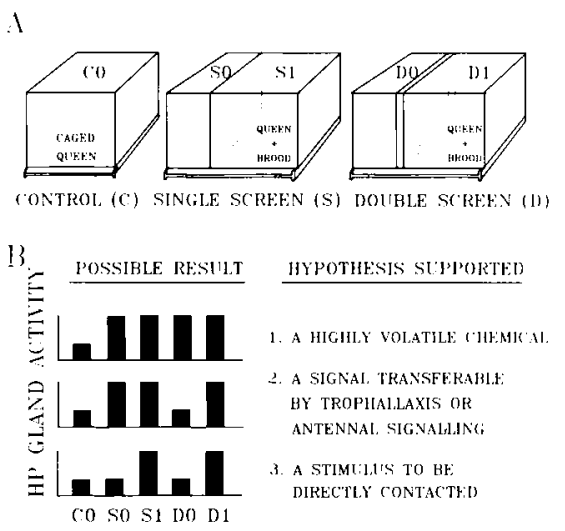

Fig. 1. Hive designs used to investigate the nature of the brood signal (A); and the three mutually exclusive hypotheses about the signal corresponding to three possible results (B).

C: completely broodless control; S: Hive separated by a single wire screen. $D$ : Hive separated by a double-screen " 0 " : broodless, "1" : broodright. 
experiment were a mixture of European bee races (Apis mellifera L.), from the Apiculture Field Laboratory, University of Guelph.

\section{Hive design}

A piece of 8-mm thick plywood cut in the shape of a Langstroth frame $(46.0 \mathrm{~cm} \times 26.5 \mathrm{~cm})$ was used to divide a single standard Langstroth hive into two parts. A rectangular hole $(37.5 \times 19 \mathrm{~cm})$ was cut in the center of the board and covered, either with a single wire screen (aperture size 3 $x 3 \mathrm{~mm}$ ) on one side of the divider (single screen), or a screen on each side of the divider (double screen). Trophallaxis across the double screen was deemed impossible, as the longest proboscis of bees (in race $A$. $m$. caucasica) is reported to be $7.2 \mathrm{~mm}$ (Ruttner, 1975). The single-screen or double-screen divider board was inserted into the hive $24 \mathrm{~cm}$ from one wall and $13 \mathrm{~cm}$ from the other (Fig. 1A), such that one side contained 6 frames and the other 3 frames. Therefore, each single hive body housed a colony divided into two isolated portions, each provided with an entrance. Five replicates of the following three designs were used for the experiment.

\section{Single-screen hive (S in Fig. 1)}

A standard Langstroth hive was separated by a single-screen board, one side with a queen and 6 frames (with 3 brood combs), the other having 3 frames with honey and pollen, but lacking a queen and brood. This design would allow highly volatile chemicals from brood to pass to the broodless side. Additionally, bees could communicate behaviourally and/or chemically across the screen through either antennation or trophallaxis.

\section{Double-screen hive (D in Fig. 1)}

This was similar to the single-screen hive except that the hive was separated by a double-screen board. Highly volatile chemicals could pass to the broodless portion of the hive, but physical contact between bees in the two portions of the hive was not possible.

\section{Control hive (C in Fig. 1)}

Similar to single-screen hive, except that the queen was caged in the 6-frame side, while no bees were put in the 3-frame side; furthermore, the divider board between the two was solid without a steel-screen. This design created completely broodless hives.

All the colonies were checked frequently to be certain they had adequate supplies of pollen and honey. If either were present in only small amounts, pollen or honey combs were provided immediately. Capped brood was removed from brood-right sides of single- or double-screened hives if they became too crowded. However, all brood-right sides of colonies always had some capped brood present.

For simplification, S, D, C will be used throughout the following text to represent hive types; 0 and 1 will be used respectively to indicate the absence and presence of brood. Thus, the three hive designs mentioned above include five treatments as shown in Figure $1 \mathrm{~A}$.

\section{Bee introduction and sampling}

Newly emerged bees from one of two source hives were colour-marked with Testor's paint and introduced to $S, D$ and $C$ hives. Different colours were used for different hives as well as different hive portions of the same hive. The marked bees were subsequently sampled on the 8th day after introduction. Some drifting occurred, but only bees which remained in the part of the hive to which they were originally introduced were sampled. The sampled bees were immediately used for the following bioassays.

\section{Measurement of HP gland activity and protein determination}

HP glands were removed from unanesthetized workers in cold Apis-saline (Brouwers, 1982). 
Pairs of intact glands from an individual bee were then put into disposable micro-centrifuge tubes containing $0.2 \mathrm{ml}$ of a simplified medium (Apis-saline plus $0.2 \%$ Ficoll 70 ) and preincubated in a shaking water bath at $34^{\circ} \mathrm{C}$ for $1 \mathrm{~h}$. After this, $0.2 \mathrm{ml}$ of medium containing 0.5 $\mu \mathrm{Ci}\left[\mathrm{U}-{ }^{14} \mathrm{C}\right]$ L-leucine $(335 \mathrm{mCi} / \mathrm{mMol}$, New England Nuclear) was added to each tube. Since a preliminary experiment showed a linear relationship between incubation time and leucine incorporation during the first $3 \mathrm{~h}$, glands were incubated for a further $3 \mathrm{~h}$. Active incorporation of the leucine into HP glands for protein synthesis could occur during this period. This uptake of leucine was terminated by adding 0.5 $\mathrm{ml}$ cold $20 \%$ trichloroacetic acid (TCA). The micro-centrifuge tubes were placed in a sonicator (maximum intensity for $15 \mathrm{~m}$ ) to disrupt the gland cells. These preparations were then stored for at least $1 \mathrm{~h}$ at $4^{\circ} \mathrm{C}$ to facilitate protein precipitation. The TCA-precipitated protein was filtered out with $1.5 \mathrm{~cm}$-diameter glass micro fiber filters (Whatman $G / A$ ), washed with $7 \%$ TCA, and dried with $100 \%$ ethanol. The filters, together with the filtered insoluble protein, were then put into scintillation vials, to which $0.5 \mathrm{ml}$ $1 \mathrm{~N} \mathrm{NaOH}$ had been added. After at least 1 , the digested protein solution was shaken, and 0.2 $\mathrm{ml}$ was withdrawn for protein determination. $\mathrm{Ra}$ dioactivity (disintegrations per minute : DPM) in the remaining $0.3 \mathrm{ml}$ of digested protein solution was determined with a Packard Scintillation Counter (Tricarb $460 \mathrm{C}$ ) with a counting efficiency of $92-95 \%$ for ${ }^{14} \mathrm{C}$.

The protein content was determined for each sample using Hartree's (1972) modified Lowry method. The results were expressed as microgram equivalents to Bovine Serum Albumin.

\section{Statistical analysis}

Values in the results section are means of the $6-12$ bees (mean $=8.6$; total $n=215$ ) sampled from each replicate $(n=5)$ within each experimental unit or hive treatment $(\mathrm{CO}, \mathrm{SO}, \mathrm{S} 1$, Do and D1 in Table 1), except in the regression and correlation analyses where the individual bee data were used.
Residual analysis indicated that the original DPM/bee data were not normally distributed. The standard errors were found to be proportional to the means of DPM/bee. Consequently, data were transformed by taking the natural logarithm of DPM to stabilize the variance. Because the broodless and brood-right sides were housed in the same hive body, the four treatments (excluding control hive) constitutes a split-plot design. Consequently, the data were first analyzed as a split-plot design; data from hive $C$ were not used. The data were then analyzed as a one-way ANOVA with 5 treatments to include comparisons to the control treatment. Regression analysis was also carried out to investigate the relationship between the gland size and amount of protein synthesized.

All statistical analysis were performed using the Statistical Analysis System (SAS version 5.16 ETS, 1985) accessed through the mainframe computer (IBM 4381-3, VM/SP 4.11) at the University of Guelph.

\section{RESULTS}

Results of the ANOVA utilizing a splitplot design

The means and their $95 \%$ confidence intervals of HP-gland activity and protein content are presented in Table I. A two-way ANOVA showed that the single- or doublescreen design did not cause any significant difference in HP-gland activity (MS=0.1, $\left.F_{1,8}=0.41, P=0.54\right)$. This indicated that the two whole-plot treatments were equal (i.e., $\mathrm{SO}+\mathrm{S} 1=\mathrm{D} 0+\mathrm{D} 1)$; in other words type of screens (single or double) did not have any effect on HP-gland activity. The presence or absence of brood had a very significant effect (MS=4.57, $F_{1,8}=64.77$, $P=0.0001$ ) upon the HP-gland activity; that 
is, when single- and double-screen hives are considered together, bees from broodright sides generally had higher HP-gland activity than those from broodless sides (i.e., $\mathrm{D} 1+\mathrm{S} 1<\mathrm{D} 0+\mathrm{S} 0$ ).

No significant interaction between screen and brood was detected (MS = $0.01, F_{1,8}+0.13, P=0.73$ ). The lack of interaction can be interpreted as follows : both brood-right and broodless sides showed no difference with regard to different screens ( $S 0=D 0, S 1=D 1)$; similarly, for both single- and double-screen hives, the difference between brood-right and broodless sides is also maintained (S1 > S0, D1 $>$ D0). Therefore, the brood-right side had a higher HP-gland activity in both singleand double-screen hives.

When the protein content was subjected to a similar analysis, an $F$ test showed no overall significance (MS=5614.70, $F_{11.8}=$ 1.92, $P=0.182$ ). In other words, neither the screen type nor the presence/absence of brood caused any significant difference in the protein contents of the tested bees.

\section{Results of the one-way ANOVA}

From the above analysis, we have not as yet established whether the broodless treatments (DO, SO) are different from the control (CO) or not. Thus the control, together with the other four treatments (SO, D0, S1 and D1) were subjected to a oneway ANOVA. The F test showed a significant effect among treatments for both variables (For HP gland-activity: $F_{4,20}=8.90$, $P=0.0003$; for protein content : $F_{4,20}=3.02$, $P=0.042$ ). Subsequently, planned contrasts were constructed comparing the broodless control over other treatments (Table II). It is clear that for HP-gland activity, the completely broodless control (CO) is the same as the broodless sides ( $\mathrm{SO}$ and D0), but different from the broodright sections (S1 and D1). However, the protein content of the broodless control is significantly higher than either the broodless or brood-right sections (Tables I and II).

Table I. HP-gland activity and glandular protein content of bees separated from brood by various methods.

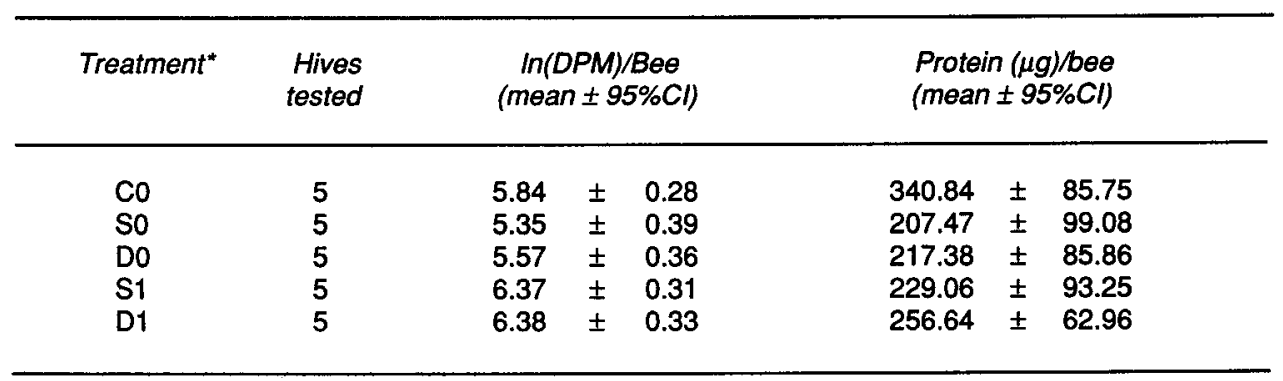

\footnotetext{
* Legends for treatments : C0 : complete broodless control; $\mathrm{S0}$ : broodless portion of single-screen hive; $\mathrm{S} 1$ : broodright portion of single-scree hive; D0 :broodless portion of double-screen hive; D1: brood-right portion of doublescree hive.
} 
Regression of DPM/bee vs protein/bee

A quadratic relation between these two variables was observed $\left(F_{2,185}=34.69\right.$, $P=0.0001$; Figure 2). Even though this overall regression was significant, this was not the case for within-treatment regression. Therefore, covariance analysis, originally planned to remove variation in DPM/ bee caused by the covariable protein content/bee, could not be carried out.

\section{DISCUSSION}

Our results have shown that brood had a significant effect on the HP-gland activity. The fact that only worker bees in the brood-right sides of hives had elevated rates of protein synthesis indicates that there is indeed a signal emitted by the brood that activates protein synthesis of HP glands, as suggested by Brouwers (1983). This signal cannot be a highly volatile chemical; otherwise, bees in the broodless sides of both $S$ and $D$ hives would have had their HP glands activated.

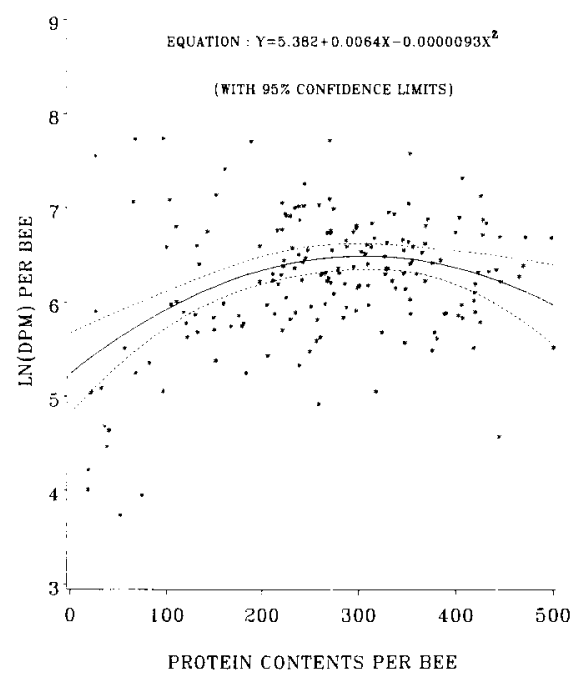

Fig. 2. Scatter diagram of HP-gland activity (in DPM per bee) against gland size (microgram of protein content per bee). The quadratic equation was fitted with a R-square of $0.27, \mathrm{df}=2,185, P=$ 0.0001 .

Furthermore, the possibility that the signal is either a chemical of low or no volatility, but transferable through trophallaxis or a behavioural signal (e.g., antennal con-

Table II. Planned Contrasts Between Various Treatments.

\begin{tabular}{|c|c|c|c|c|c|c|c|c|}
\hline \multirow[t]{2}{*}{ Contrast } & \multicolumn{5}{|c|}{ Coefficients } & \multirow{2}{*}{$\begin{array}{l}\text { Sum of } \\
\text { Squares }\end{array}$} & \multirow{2}{*}{$\begin{array}{c}F \\
\text { Value }\end{array}$} & \multirow[t]{2}{*}{ Pr. } \\
\hline & $\mathrm{CO}$ & So & & & $D 7$ & & & \\
\hline \multicolumn{9}{|l|}{ Gland Activity : } \\
\hline Control vs brood & -2 & 0 & 0 & 1 & 1 & 1.11 & 8.9 & $<0.01$ \\
\hline Control vs no brood & -2 & 1 & 1 & 0 & 0 & 0.48 & 3.8 & ns \\
\hline \multicolumn{9}{|l|}{ Protein content: } \\
\hline Control vs brood & -2 & 0 & 0 & 1 & 1 & 54970.7 & 11.4 & $<0.01$ \\
\hline Control vs no brood & $-\overline{2}$ & 1 & 1 & 0 & 0 & 31033.1 & 6.4 & $<0.05$ \\
\hline
\end{tabular}


tact), can also be ruled out. This is evident because bees from the broodless side of $S$ hives, which could make food exchange and mutual antennation with bees from the brood-right side, did not show elevated HP-gland activity compared with the broodless bees from $D$ hives or $C$ hives. Thus, it can be concluded that adult bees must contact the brood directly in order to have their HP glands activated.

There is always the possibility that not "enough" volatile chemical was passed, or that not "enough" trophallaxis occurred, in the single-screen hives to convey the signal. However, the asymmetrical design of the hives, with six frames on the broodright side and only three frames on the broodless side, was adopted in order to prevent this type of effect. It was also observed that significantly more bees stayed on the single-screen than on the doublescreens, and many of them were observed engaging in mutual antennation and trophallaxis across the single scree. The failure to detect any brood effect when separated from the screens could also be attributable to the insufficient number of samples. However, in this case, one should not have found the HP-gland activity from broodless sides of $D$ and $S$ hives to be slightly lower than from bees in control C. Therefore, it is believed that enough samples were taken to detect any brood effect.

Some similar studies have been conducted previously to investigate other possible brood signals. Jay (1972), using a similar single and double-screen method, suggested there was a volatile brood (or brood-related) scent which acted to inhibit ovarian development in worker bees. When investigating the signal which promotes pollen collection by honey bee foragers, Free (1967) put single- or doublewalled wire-gauze cages containing brood and nurse bees into test colonies. He showed that foragers excluded from brood by double-walled cages collected less pollen than those excluded from brood by single-walled cages, but that they collected more than those with both brood and brood odour absent. Therefore, the stimulus for pollen collection could be transmitted across a double screen, indicating the presence of a volatile component. It seems that the signal being investigated here is neither the pheromone(s) nor factor(s) investigated in the above studies, since the signal being investigated requires direct contact.

Koeniger and Veith (1983) identified a contact brood pheromone (glyceryl-1,2dioleate-3-palmitate) which induces warming behaviour by adult workers. The pheromone may also be important as a general signal indicating the existence of brood (Koeniger \& Veith, 1984). While this pheromone could be used as a signal for HP gland activation, it is unlikely for two reasons. First, while the pupal stage was found to contain the pheromone component (Koeniger \& Veith, 1983), it was ineffective in inducing HP gland protein production (Huang \& Otis, in press). And second, olive oil, which was reported to have similar effects as synthesized pheromone (Koeniger \& Veith, 1983), also failed to activate HP glands (Huang, 1988).

The fact that HP-gland activation requires direct access of worker bees to brood does not necessarily mean that a surface pheromone is involved. Indeed, there could be a pheromone with a small active space from the brood, but physical properties of the cubicle or even a behavioural signal from the brood are other alternatives. Further experiments are required in order to decide which of these factors is operating.

All broodless bees (bees from $\mathrm{CO}$, SO and Do) had comparable low HP-gland activity, yet bees from completely broodless 
hives ( $\mathrm{CO}$ ) had significantly higher protein contents than either broodless bees separated from brood (SO, D0) or brood-right bees (S1, D1). Therefore, it appears that some factor from the brood was influencing the development of the glands, but not the ability of the gland to synthesize protein; and also this factor could travel through both kinds of screen. In addition, it is of interest to note that this factor actually inhibited rather than stimulated HP-gland development. It is therefore quite clear that the brood factor influencing the gland development is different from the one affecting the activation of protein synthesis.

While Brouwers (1982) reported that there was no "apparent correlation" between the gland size and gland activity, a significant quadratic relationship was found in our study between the two variables. This could be due to the larger sample sizes or different experimental conditions used in this study. The curvilinear relationship found is consistent with observations that undeveloped glands (smallsized glands) have lower gland activity (Huang, unpublished data), and that hypertrophied glands (large-sized glands) also have lower gland activity because they are usually associated with broodless conditions (Brouwers, 1982). Thus, medium-sized glands are more likely to be active and associated with brood rearing. It is possible that when brood is absent, the protein secretion is "un-used" and inhibits further secretion (i.e. synthesis) by a negative feedback mechanism, as suggested by Huang (1988). Since the relationship between the gland size and activity is not straightforward, using the morphology and/ or size of the gland as measures for estimating the gland activity (Hassanein, 1952; Maurizio, 1954) may not be adequate.

\section{ACKNOWLEDGMENTS}

The authors are indebted to R.W. Shuel and S.E. Dixon for valuable advice and discussions. Thanks are due to Ava Yu for her technical assistance in dissecting some of the glands. R.W. Shuel, D.J.C. Fletcher, C. Scott-Dupree, D.L.G. Noakes and D.B. McKeown critically reviewed an earlier version of the manuscript. Two anonymous reviewers also gave helpful criticisms and suggestions. The project was partly supported by a Chinese scholarship and a CIDA scholarship to Z-Y. Huang, and a grant to G.W. Otis from the Natural Sciences and Engineering Research Council of Canada. This research constitutes partial fulfillment of requirements for the Ph.D. degree at the University of Guelph.

Résumé - Nature du signal, émis par le couvain, activant la synthese des protéines dans les glandes hypopharyngiennes de l'abeille, Apis mellifica L. (Hym. Apidae). Les données suggèrent l'existence d'un signal émis par le couvain de l'abeille, qui active la synthèse des protéines dans les glandes hypopharyngiennes (HP) des abeilles nourrices. On a étudié la nature du signal en mesurant l'activité de synthèse protéique dans les glandes d'abeilles séparées du couvain de diverses façons. L'activité glandulaire a été mesurée par la méthode in vivo de Brouwers (1982) modifiée.

On a utilisé 3 structures différentes de ruche (Fig. 1A) : une ruche totalement dépourvue de couvain et des ruches avec une partie sans couvain, séparée du couvain, soit par un grillage simple, soit par un grillage double. Les 3 résultats possibles correspondent chacun à l'une des 3 hypothèses s'excluant mutuellement : le signal est :

- un composé chimique volatil,

— un stimulus transmissible par la communication par antennes ou par trophallaxie, 
- recevable seulement par le contact direct avec le couvain (Fig. 1B).

Alors que l'existence de grillage à l'intérieur de la ruche n'a eu aucune influence sur l'activité des glandes HP, la présence ou l'absence de couvain a induit une différence significative (Tableau I). Une analyse plus poussée a montré que les portions sans couvain, qu'elles soient séparées du couvain par un grillage simple ou double, avaient une activité glandulaire HP aussi faible que le témoin totalement dépourvu de couvain. Par contre, dans les deux types de ruches avec grillage, les portions avec couvain avaient une activité glandulaire HP significativement plus élevée (Tableau II). On en conclut que les ouvrières ne peuvent recevoir le signal que si elles ont un contact direct avec le couvain.

L'analyse de la régression a montré qu'il y avait une relation quadratique entre la teneur totale en protéines et l'activité glandulaire HP (Fig. 2), ce qui indique que les glandes sous-développées comme les glandes hypertrophiées sont moins susceptibles de synthétiser des protéines que les glandes de taille intermédiaire.

\section{Apis mellifica - glande hypopharyn- gienne - synthèse protéique - cou- vain}

\section{Zusammenfassung - Art des Brutsi- gnals für die Aktivierung der Protein- synthese in den Hypopharynxdrüsen der Honigbiene. Es liegen Beweise für die Existenz eines von der Bienenbrut ausge- henden Signals vor, das die Proteinsyn- these in den Hypopharynxdrüsen (HP) der Pflegebienen aktiviert. Die Art dieses Sig- nals wurde in dieser Studie durch Mes- sung der Proteinsynthese-Aktivität in Drüsen von Bienen gemessen, die in vers- chiedener Weise von Brut getrennt wur-}

den. Die Drüsenaktivität wurde nach einer abgeänderten in vivo Methode nach Brouwers (1982) gemessen.

In diesem Experiment wurden drei verschiedene Situationen des Bienenvolkes verglichen (Fig. 1A) : Ein gänzlich brutloses Volk und Völker mit einem brutlosen Abteil, das von der Brut entweder durch ein einfaches Gitter oder durch ein Doppelgitter getrennt war. Von den drei möglichen Resultaten würde jedes für sich eindeutig je einer der drei möglichen, sich gegenseitig ausschließenden Hypothesen entsprechen : 1) ein sehr flüchtiges chemisches Signal, 2) ein Signal übermittelt durch Antennenkontakt oder durch Trophallaxis (Futteraustausch) zwischen adulten Bienen, oder 3) ein Signal, das nur durch direkten Kontakt mit der Brut weitergegeben wird (Fig. 1B).

Während alle Typen mit Gittern keinen Einfluß auf die HP-Aktivität zeigten, verursachten Fehlen oder Vorhandensein von Brut signifikante Unterschiede (Tabelle I). Weitere Analysen zeigten, daß alle brutlosen Abteile, gleichgültig ob durch einfache oder Doppelgitter von der Brut getrennt, dieselbe niedrige HP-Aktivität zeigten wie die völlig brutlosen Kontrollen; die Abteile mit Brut in beiden mit Gittern versehenen Volkstypen hatten dagegen signifikant höhere HP-Drüsenaktivitäten (Tabelle II). Es wird daraus geschlossen, daB die Arbeiterinnen das Signal nur erhalten, wenn sie direkten Zugang zur Brut haben.

Regressionsanalysen zeigten eine quadratische Beziehung zwischen Gesamtproteingehalt und HP-Drüsenaktivität (Fig. 2). Das weist darauf hin, daß sowohl unentwickelte und hypertrophierte Drüsen weniger wahrscheinlich Protein aufbauen als Drüsen von mittlerer Größe.

\section{Honigblene - Hypopharynxdrüse - Proteinsynthese - Brut}




\section{REFERENCES}

Brouwers E.V.M. (1982) Measurement of hypopharyngeal gland activity in the honey bees. $J$. Apic. Res. 21, 193-198

Brouwers E.V.M. (1983) Activation of the hypopharyngeal glands of honey bees in winter. $J$. Apic. Res. 22, 137-141

Buhler A., Lanzrein B. \& Wille H. (1983) Influence of temperature and carbon dioxide concentration on juvenile hormone titre and dependent parameters of adult worker honey bees (Apis mellifera L.). J. Insect Physiol. 29, 885893

Fluri P., Lüscher M., Wille H. \& Gerig L. (1982) Changes in weight of the pharyngeal gland and haemolymph titres of juvenile hormone, protein and vitellogenin in worker honey bees. J. Insect Physiol. 28, 61-68

Free J.B. (1967) Factors determining the collection of pollen by honey bee foragers. Anim. Behav. 15, 134-144

Hartree E.F. (1972) Determination of protein : a modification of the Lowry method that gives a linear photometric response. Anal. Biochem. 48, 422-427

Hassanein M.H. (1952) The effects of infection with Nosema apis on the pharyngeal salivary glands of the worker honey bee. Proc. $R$. Entomol. Soc. London, 27A, 22-27

Huang Z-Y. (1988) Mechanism of hypopharyngeal gland activation by brood of honey bees
(Apis mellifera L.). Ph. D. Dissertation, University of Guelph. p. 154

Huang Z-Y. \& Otis G.W. (1989) Factors determining hypopharyngeal gland activity of worker honey bees (Apis mellifera L.). Insectes Soc. (in press)

Jay S.C. (1972) Ovary development of worker honey bees when separated from worker brood by various methods. Can J. Zool. 50, 661-664

Jung-Hoffmann I. (1966) Die Determination von Königin und Arbeiterin der Honigbiene (Apis mellifera L.). Z. Bienenforsch. 8, 296-322

Koeniger N. \& Veith H.J. (1983) Glyceryl-1,2dioleate-3-palmitate, a brood pheromone of the honeybee (Apis mellifera L.). Experientia 39, 1051-1052

Koeniger N. \& Veith H.J. (1984) Spezifität eines Brutpheromons und Bruterkennung bei der Honigbiene (Apis mellifera L.). Apidologie, 15, 205210

Maurizio A. (1954) Pollen nutrition and vital processes in the honey bee. Landw. Jb. Schweiz., $68,115-182$. IBRA translation No. E368

Ruttner F. (1975) Races of bees. In : Hive and the Honey Bee (Dadant \& Sons, eds.), Hamilton, IL, pp 13-38

Rutz W., Gerig L., Wille H. \& Lüscher M. (1976) The function of juvenile hormone in adult worker honey bees, Apis mellifera. J. Insect Physiol. 22, 1485-1491

SAS Institute Inc. (1985) SAS User's Guide : Statistics, Version 5 (Cary ed.), North Carolina 